\title{
Crisis of Morals and Values: A Bangladesh Perspective
}

\author{
Md. Matiur Rahman ${ }^{1}$, Md. Abdullah Al Younus ${ }^{2}$, Md. Kamal Uddin ${ }^{3}$ \\ ${ }^{1}$ Professor, Dean, Faculty of Arts \& Social Science; Vice-Chancellor (In Charge), Britannia University, Comilla, \\ Bangladesh \\ ${ }^{2}$ Lecturer, Dept. of English, Feni University, Feni, Bangladesh \\ ${ }^{3}$ National Volunteer, JANIPOP, Bangladesh \\ Correspondence: Md. Abdullah Al Younus, Lecturer, Dept. of English, Feni University, Feni, Bangladesh.
}

Received: September 3, 2018

Accepted: October 8, $2018 \quad$ Available online: October 12, 2018

doi:10.11114/ijsss.v6i11.3687

URL: https://doi.org/10.11114/ijsss.v6i11.3687

\begin{abstract}
The morals and values which are held in high esteem are now eroding with the progressing trend of modern civilization. This decline has taken a dangerous turn and in consequence it is very difficult for the peace loving people to bear the miserable aspects of life. Relevant examples have been cited from different scenarios of national and international level to evaluate the gravity of the situation resulting from moral degradation owing to the loss of ethics and values among people of all walks of life. The causes of this vicious state of life have been examined in the study through questionnaire and interview with different sections of people. As it is a topic of great interest, teachers, learners and social elites showed keen sense of interest to reflect their opinions as far as the cause and effect of this crisis are interrelated to make the discussion thought provoking and fruitful. The objective of the study is to raise awareness among the people and the practical utility of morals and values. The result of this survey has been thoroughly analyzed and effective suggestions are given for making concerted efforts for solution so that the problem may not destroy our glorious achievement for the country we have so far done right from our independence. Just like all authors valuable research papers we, the writers have spared no pains to mention some objectives in a crystal clear manner keeping abreast of our sincerest attempts to state what our principal goals are and what we really aspire to achieve, par excellence providing relevant data to the best of our ability with vigorous studies that opened a new horizon to us in this field. Change of mind set and above all a holistic stance toward it may invigorate us to eliminate the evil and inculcate proper values and morals for national standard and eminence both at home and abroad.
\end{abstract}

Keywords: morals and values, crisis, decline, vicious, social, religious, Bangladesh

\section{Introduction}

The present age in which we are living is an age of declining morals and values in every sphere of the society. It does not remain confined within the boundaries of a country but it has become a concern. In a densely populated country like Bangladesh which is progressing by leaps and bounds is experiencing the sharp decline of morals and values among the youths although some aged people are also lacking moral standard. It leads man and woman from the path of ethical consideration to moral degradation for which they are bound to be corrupt and vitiated and thus become a potential damages for the country. People are struck with remorse when some high ups of the society are found implicated in immoral activities and the media expose and bring them to the spotlight. As for instance if we go through the daily newspaper and think in terms of it we can easily understand where we are. Why does the mother kill her children? Or why does the son kill his father? What causes are there within the wife leaves her husband? Or when the husband leaves the wife? Why does a section of people leak out question paper knowing full well education is the backbone of a nation. What we want to say is the occurrence of rampant crimes and vices in the society from the lower class to the higher class. Incompetent persons are seen to seek favor through bribery. There are hundreds and thousands of immoral practices in which people take part to serve their illegal purpose. Do they ever think whether such evil practices are right or wrong or whether these are allowed by law or religion? The fear of God and justice both here and hereafter has no compassion to them. They are heedless to religion and law of the land. If we look through the lence at the international level some living pictures will flash upon our minds which are sure to cause tear roll down from our eyes like misty, rain. A look at the innocent Rohyngas fleeing from their homes in Rakhaine State and living at the refugee camp in Bangladesh or being tortured by the savagers. Innumerable numbers of Muslims killed in Bosnia and 
Hergegibina and the tragedy of the homeless Palestenians losing their territories due to the brutal occupation by the Israelies. The foolish war in Yemen, Syria and Iraq are nothing but an act of barbarism. Numerous examples are cited from the international perspectives. We are to focus from the Bangladesh perspective. It is known that Bangladesh is liberated from the brutal regime of Pakistan that colonized her for long time. The after effects or impact of their tyrant and oppressive rule has its indirect effect on the morals and values of our people. It will take a great deal of time to overcome the legacy of the past of which our present government is quite aware and making attempts to root out all evils from the country. We think it is not a one sided task but concerted effort must be made to achieve important breakthrough. It is true that the modern civilization is a kind of mechanical civilization where everybody is concerned with material possession and development without caring for moral elevation and standard. Once the social motto was each for all and all for each but at present we see that every man is for himself. People take pride in their self-aggrandizement and self-satisfaction. The ailing father is weeping in bed in the hospital and the son has no time to see him.

A next door neighbor is ill-clad and without food. Man has become so careless about his surrounding that he does not think of the sorrows and sufferings of his fellow-men. Those who do not feel compassion for others and kind to man are not truly educated. A truly educated person has fellow-feeling and is sympathetic. The crisis of morals and values has rendered man to animals in nature. To some people animal nature dominates more that the human nature. Jonathan Swift once said, "The more I see man the more I like to see the dogs." The lack of morals and values is eating into the vitals of our society. The learned man has no value in the estimation of the moneyed man or the industrial magnates. Our outlook has become so materialistic that we hardly attach importance to the educated man in the society. Social status and distinction are counted through boundless wealth and possession though gained through unfair means. So it is said those days of plain living and high thinking are no more. The wealthiest man among us is the best. The young generation hardly tries to build up their characters and maintain its sanctity and integrity even though they read volumes after volumes of books in the curricula. The result is that they are becoming graduates and post graduates without any moral education. In the holy Quran Allah said, "They are aware of the external aspects of the world but they have no knowledge of the other world." Without morals and values there can be no character formation. So even the best student in the class devoid of moral character is beyond to indulge in unlawful acts in the subsequent stage of his life particularly when he holds a dignified part in the helm of power.

A higher educated man having a bad character is a potential danger to the state. So the topic on which we are writing is a great importance and our aim of this research is to bring forth its implication viza-vis the reality of our situation with possible hints and recommendations how to nurture and develop it in personal, social and national life. In this respect it is important to have an awareness of our country's approach to this problem so that we can stand the test of time. It is to a large extent a burning issue without the solution of which we shall be at risk to survive as a proud nation. We have at the inception made our earnest endeavor to bring home to all the crux of the evil prevailing among us so that it may not linger as hard nut to crack. Nothing is impossible to the willing heart and as such everything in this respect depends on the determination we take towards this moral crisis.

The main purpose of the research paper is to find out the severity of the crisis of morals and values existing everywhere even from the grassroot levels. We have sought the point of view of some elites of the society, the university students and teachers. We made a threadbare discussion with them for critical analysis of the problems. However, the present study has been designed to examine the chronic problem and identify concrete remedial measures of solution. The objectives of this study are: (i) to analyze the present state of the crisis of morals and values in our society in Bangladesh. (ii) to explore different strata of the society where the moral degradation persists.(iii) to find the challenges in the way of effective solution. The findings of the research will build up social awareness among all people and would benefit the government for making policy in this respect.

\section{Literature Review}

Morality is considered the first and foremost asset of a human being. A man having this quality do good to himself, his family, society, the country he was born and living in and the world as well. Aristotle believed that, while any state must prepare its citizens for useful pursuits (the economic and the military), these are secondary. 'It is true ...he said. 'that they must be able to do necessary or useful acts; but they must be even more able to do good acts' (Barker, trans., sec. 1333b, p. 373)

According to Schweneke (2002), Abass (1998) and Global Planning Education Association Network (2009) urbanization and industrialization is main cause of crisis of morals and values. In urban areas there are human suppression and poverty, robbery, smuggling, increasing of illegal sex and lust, availability of alcohol, scarcity of employability and so on. Fraudulency, cheating, deceit, false pretence and corruption have become the common phenomenon in church of Nigeria Iheanacho ((2010) and David-west in Ebhomele and Ateba (2013). 
For colonial and business purpose the Western people came to Indian sub-continent. They ruled this subcontinent for almost two hundred years. They spread their education system. Through their education system the people of Bangladesh got habituated with the influence of tradition or techniques of education system Merriam-Webster Dictionary (2013). This western education and westernization have disastrous effects on the morality of the people of Bangladesh.

There are Muslim scholars who adhere to their Islamic values, religion and behavior and they also achieved vast progress in scientific and technological fields. The Holy Quran is a methodology of morals and virtue, that is stated the rules of morals, and drew the path of right behavior that achieves happy life to all society individuals. Quran is only a Book that contains guidelines that are pertinent to performing religious rituals and there is nothing else in it. The fact is that in Quran Almighty Allah has given the complete guidelines and said that humanity is whatever they want to know about this universe in general and the way of living life in particular. Islam puts great emphasis on the height of characters and for this purpose it encourages the followers to adopt good moral qualities in their lives. In this regard, the life of Prophet Muhammad (PBUH) stands as an evident and clear example for Muslims and from him they can learn what the height of moral is like. In the Quran, there are mentions of numerous moral values that a Muslim should incorporate in his or her character.(Al-Quran Sura Imran: 17) morality teaches man code of conduct to help segregate truth from falsehood Ameer Hamzah (2013). morality develops the conscious of human beings by which a man can judge a thing whether it is good or bad, right or wrong Ameer Hamzah (2013). It helps a man choose the proper way to become a complete man. Continuous practice of moral virtues and a conscious effort to internalize those qualities can lead to the formation of a morally good character. Birgivi (2005). Al Hadith contains the morals and values. Allah has said that prophet Mohammad (P.B.U.H) is the testimony of the best character for his ummah and they should follow him.

\section{Methodology}

To carry out the study mixed method was followed as it is close to the aims and objectives of this study. The first thing that had been done is the preparation of a questionnaire with twenty questions for evaluation of the topic. The study was conducted on 100 tertiary level students from three universities At first Comilla Victoria College was selected for experiment with the questionnaire in the classroom consisting of 30 students of first year Honours in Islamic History and Culture. All the students read the questions individually and expressed their reaction. They admitted the fact that there is crisis of morals and values among them as well as in the society.

Next a classroom of Hon's $3^{\text {rd }}$ year $1^{\text {st }}$ semester consisting of 32 students of the Department of Economics at Comilla University was visited where the learners properly answered the questions and opined that the crisis of the morals and values is a long-standing issue which is easy to understand but difficult to solve. And finally 38 students at Britannia University at Comilla who expressed their individual opinions about the issue. They thought that it was a challenging task for the country which was beset with corporation and other malpractices. In the second stage we made an arrangement to interview ten teachers of Comilla University asking them questions about the condition of morality in our country. Their opinions about this issue is that it had become an epidemic in our country in every circle the society. It will not be possible to solve it by the teachers and students. So, it demands coordinated effort from sections of people. This was followed by the meeting with further 10 college teachers of Comilla who agreed with the researchers that there was a sufficient example of moral lapse in the society. Their suggestion was the spread of moral education among the students of different schools, colleges and universities of this country. In the third stage we explained our views with the Focused Group consisting some Madrasha principals and and Khatibs of Juma Masjids who expressed their sharp reactions about this miserable condition of morals and values every sections of the society. They emphasized the need for religious education for want of the situation deteriorating day by day. They reiterated that the teaching of the Holy Quran and Hadith is of paramount necessity for lasting solution. Besides them we involved some political figures Chairman of Upazilla Parishad and some well-known social workers who unanimously shared their opinions but stressed the need for moral persecution by the guardians. They pointed their fingers to the laws of the land to deal with the issues.

In the end an intensive survey was made in the rural areas of Comilla District where having conversation with some literate people who expressed great shock about the seriousness of the problem from which no family was spared. They gave clear opinion about the sitution of the increasing trend of this social issue. They pointed out an important step for the implementation of every family living in their union should educate their sons and daughters properly. According to them if anyone is found violating the moral code should be taken into account so that no such violation of moral conduct ever repeated.

\section{Analysis}

\section{Social Point of View}

A close analysis of the study demands national response with a view to finding the inevitable causes and factors that are 
mainly responsible for these ills of the present society. The structure of the society is complex where there is undue concentration of wealth among the rich and the aristocrats. As a result the rich are becoming richer and the poor poorer. This social gap has given rise to economic disparity between beneficiaries and the deprived classes. To this comes the problem of unemployment among the youths who have received higher education but still they are jobless and had to depend on their parents as parasites. There is growing frustration among them. The hard realities of life has rendered them pessimistic and aggressive. This breeds violence, anger, hatred, jealousy and discontent that-consequently implicate them into immoral, irreligious and other anti-state and anti-social activities that are condemned as criminal offences like, rape, homicide, disappearance murder, conflict etc. Some political leaders are often busy to satisfy their personal gain and cannot fully maintain their chain of command and sometimes they fail to strengthen their footing at the grass root level where there is frequent infighting over individual interest which goes above the interest of the party as well as the country.

In the bygone days, there was cordial relation among people in the communities. There was mutual honor and respect: With the passage of time social relationship has been shattered like a pack of cards. Love, affection, sympathy and fraternity which were once the foundation of social fabric have now become insignificant. Once the bonding of the family was very strong and solid. Misunderstanding between husband and wife and unexpected divorce have psychological effects among the children in those broken families are disastrous for the society. This situation has been aggravated by the evils of cultural aggression, technological advancement in the shape of face book, twitter, abuse of internet and violent movies.

This sorry state of moral degradation of the society should not be allowed to destroy our age old values and traditions that our ancestors worked hard to teach us. For this purpose, the family tie should be reestablished and the children must be taught the spirit of moral education. The social elites, political leaders have a key role to play in collaboration with the spiritual leaders and teachers of different institutions. The government should also come forward with its state policy to raise the moral standard and rectitude of our people. Until and unless adequate measures are taken all achievements of our nation will be nipped in the bud.

For this objective to achieve observatory cells may be established in different districts and upazillas with its headquarter in Dhaka to monitor and watch the current trends of the moral and ethical values. For better observation and improvement frequent seminars and conferences may be held in the Schools, Colleges, Madrashas and Universities where maximum number of people should participate so that the message may be widely circulated in the society. As a matter of fact our families are the original and basic centers for teaching and learning morality. If the parents take due care to teach their children certain norms and values: some dos and donts they will follow them as important guidelines to conduct their lives in all the stages of their lives. The fruitful education that they will receive from their families will last long and as such they will never deviate from the moral principles such as love for god, respect for authority, respect for life, love of truth, allegiance to family, society and state, tolerance and respect for human rights. Social and individual sense of awareness is essential to check the alarming increase in crimes in different sections of the society.

Sometimes due to the defects of our system of education the moral crisis grows. We get knowledge of material well being and prosperity without fostering human values. This type of education may give higher degree and good certificates that may be helpful in getting good job or generating income but it makes the so called educated persons devoid of morals. It is not at all peace and tranquility in the society. That which is false actually troubles the mind but truth brings the triumph of peace. The test of morality can be experienced by what the society does for its children. If there is adequate arrangement for morality development among the children, they are sure to grow up with ethics and values and will never deviate from the righteous path even when they are tempted with unlawful offers. A man of values is greater than a man of success. The success that man attain prolong but with the touch of truth it will dwindle into nothing. Man having social and religious value even with scanty income is generally held in high esteem. A corrupt person is always looked down upon by all.

Mental and moral development are correlated with each other. Mental development is nothing but cow dung without moral elevation. If a nation educates its people laying more emphasis on the development of mind without developing the morals it akin to educating the menace that will inevitably ruin the entire society. This is because the precondition of the formation of character, the glory of life is moral upliftment. The integrity of national character can largely enhance the national image and prestige of a state both at home and abroad. All kind of development, political, social, cultural and economic are greatly associated with national character.

\section{Religious Point of View}

Human beings are blessed with wisdom and free will and are given a status above that of all the other living beings. On the basis of these blessings, humans are expected to live a life conforming to moral and ethical values. Morality or the propagation of moral values is a major aspect of Islam. People of today think of Quran as only a Book that contains 
guidelines that are pertinent to performing of religious rituals only and there is nothing else in it. If everyone follows morality in its best form, the world will become a much better place to live. There are Muslim scholars who adhere to their Islamic values, religion and behavior and they also achieved vast progress in scientific and technological fields. The Holy Quran is a methodology of morals and virtue, that is stated the rules of morals, and drew the path of right behavior that achieves happy life to all society individuals. Allah states in the Holy Quran (Surely, this Qur'an guides to what is most right; and gives to the believers who do good deeds the glad tidings that they shall have a great reward (Al-Quran 17:09), and that (And if there comes to you guidance from Me, then whoso will follow MY guidance, will not go astray, nor will he come to grief (Al-Quran 20: 123), and the Holy Quran is the constitution of morals in Islam. In Quran, there are mentions of numerous moral values that a Muslim should incorporate in his or her character. The lines below discuss a few of such major moral values." (They are) those who are patient, those who are true, and obedient with sincere devotion in worship to Allah and those who spend (their wealth as Zakat and alms) and those who pray and beg Allah's Pardon in the last hours of night." (Al-Quran 3:17)

Morality is a comprehensive term that serves to include the concept of righteousness, good Character and the body of moral qualities and virtues prescribed in Islamic thought. The idea of Islamic morality is that of love, love for God and love for God's creatures. The idea is that mankind will acquire and follow the body of moral qualities in order to seek God's pleasure and to treat the fellow human beings in the best possible manner (Leaman 2006,p 416). Morality deals with internal affairs of man whereas law deals with external affairs. Marality teaches man code of conduct to help segregate truth from falsehood. (Ameer Hamzah, 2013) Morality develops the conscious of human beings by which a man can judge a thing whether it is good or bad, right or wrong. It helps a man choose the proper way to become a complete man. Morality is related to humanity. It also studies logic and reason of what he will do. Then he executes his plan. Whatever he wants to do, he must have moral power.

Character primarily refers to the assemblage of qualities that distinguish one individual from another. Character can be good or bad. A good character is the one that has good moral qualities. There was a debate among the early Islamic moralists as to whether character could be changed. They recognized the dual aspect of character "innate and acquired "and thus noted that with conscious practice it could be changed to a certain degree. As a religion Islam promotes the idea of good character as is evident from its canonical texts. The Quran describes Muhammad (P.B.U.H) as being 'on exalted quality of character ('Al-Quran 68:4) and refers to him as 'an excellent example' (Al-Quran 33:21) which ultimately means that the religious and moral examples, set by Muhammad (P.B.U.H), are to be followed and cultivated by the Muslims in order to construct a morally good character. Muslim moralists have discussed the ethics religion importance of having a good character as well as the ways of acquiring it. Imam Birgivi, says that 'To cure yourself of a bad feature of character is an obligation'. There are numerous sayings of Muhammad (P.B.U.H) that highlight the importance of good character. Some of these are

Anas ibn Malik reported that the Prophet said: The one with good morals and character already owns the best of this world and the Hereafter (Tabarani and Birgivi, 2005)

> Abu Hurayrah reported that the Prophet said: I have been sent for the perfection of character (Imam Ahmad and Bayhaqi, Birgivi, 2005)

Anas ibn Malik said that a person reaches the best and most honored levels in the Hereafter as a result of good character .Trustworthiness, which is connected to fulfilling assigned responsibilities properly, has a wide field of application in Islam and conveys a wide range of meaning (Al-Quran 4:58). Islam has made every person responsible for returning the trust to their due recipients; and this command applies to both the common people and the ruling men (Al-Quran 4:58) Misappropriation or breach of trust has been condemned severely. Anas ibn Malik narrates that there was hardly any occasion where Muhammad (P.B.U.H) had delivered a speech but he had not said this "The person who lacks trustworthiness also lacks faith. And the person who does not keep promises has no religion." Muhammad has said, "Every one of you is a guardian and everyone will be asked about his subjects. Imam is a guardian. He will be asked about his subjects. A man is the guardian of the persons in his household. He is answerable about them. A woman is the guardian of her husband's house. She will be asked about her responsibility. The servant is the guardian of the articles of his master. $\mathrm{He}$ is answerable about this responsibility of his" (Sahih Muslim, Chapter 20, Hadith 4496).Performing one's duty sincerely and honestly is a trust. It means that a person will have the intention to properly carry out the duties entrusted to him, and will do it in the best possible manner without indulging in corruption( Al-Ghazali chp 8,). Adi bin Umaira narrates that he has heard the Prophet as saying: "Whomsoever we have given some post and he has concealed a needle or a thing smaller than that, then it will be a misappropriated thing with which he will have to appear on the Day of Judgment"(Sahih Muslim Chapter 20,Hadith 4514). To deny the public posts to those whose deserve them most, or to make appointments at public posts through nepotism is seen as misappropriation against God, His messenger, and the people. Those who make such unfair appointments have been warned that their prayers would not be accepted, and hell would be their destination (Al-Quran 4: 58). Sahih Bukhari narrates that a man asked Muhammad (P.B.U.H) when the 
Doomsday would occur. Muhammad replied "When deposits in trust would start being lost, then wait for the Doomsday." He was asked again, "What is the meaning of loss of trusts?" He replied: "When responsibilities are entrusted to unfit persons, then wait for the Doomsday". (Sahih Bukhari chapter 8, Hadith 506). Person to the lowest depths of Hell. The description stated above about the significance of good character and trustworthiness which are the remedy of morals crisis and its values.

Numerous verses of the Quran and the sayings of Muhammad tell the Muslim to be generous with their wealth and to respond to the calls of the mankind's needs. Muslims believe that spending wealth for others, especially for the needy, and helping people are a fundamental duty for them and these things earn God's mercy and reward in the afterlife. Similarly, caring for one's kinsmen and neighbors has also been emphasized. The Quran says that the righteous are those people who fulfill their promises, and feed the needy, the orphans and the captive for the love of God(Al-Quran 76:5-8).At another place, it says "Those who (in charity) spend their goods by night and by day, in secret and in public have their reward with their Lord; on them shall be no fear, nor shall they grieve"(Al-Quran 2:274).In a long hadith collected in The Sahih Muslim, helping people in time of their needs is seen more important than praying in the mosque. To forgive a person who has done moral offense, and not to be cruel to him is seen as a noble virtue (7:199). In Islamic religion, the act of forgiveness is not meant to deny or underplay the moral injury suffered by the victim; rather it involves a positive change in mentality toward the offender. Thus, an act of forgiveness means rising above one's self-interest or narrow-mindedness, and achieving nobler quality of heart. Those who practice the act of forgiveness have been promised reward by God. In a frequently quoted hadith, Muhammad (P.B.U.H) is reported as saying: 'the best deeds before God are to pardon a person who has wronged you, to show affection for relatives who have broken ties with you, and to act generously towards a person who has deprived you'. Honesty implies maintaining sincerity and truthfulness in all actions, interactions, and transactions, and the issue of honesty touches almost all aspects of human life. Here, honesty serves as a umbrella term having some basic components like speaking truth; fulfilling commitments, whether written or verbal; remaining truthful to one's word; rendering the assigned duty sincerely and as meticulously as possible; imparting everyone's due rights without the person's asking for it; being objective in evaluating any case and giving judgments; avoiding falsehood, deception, and favoritism. The Quran and the hadith describe God as being kind and merciful to His creatures, and tell people to be kind likewise. Among the 99 Names of God in Islam, the most common and famous are "the Compassionate" (Al-Raḥmān) and "the Merciful" (Al-Rahīm) (Bentley, David, 1999) The Quran says, "Verily, Allah is kind and merciful to the people"(Al-Quran 2:143) Numerous sayings of Muhammad tell the Muslims to be kind and merciful to the creatures of God. In Sahih Bukhari, it is said "He who is not merciful to others, will not be treated mercifully (by God)" Sahih Al-Bukhari chap. 8, Hadith 42). Narrated in Sahih Muslim, Muhammad said, "Verily, Allah is mild and is fond of mildness, and He gives to the mild what He does not give to the harsh". He also said, "He who is deprived of kindness is in fact deprived of goodness Muhammad has been described as being kind and compassionate to people and animals Sahih Muslim chap. 32, Hadith 6273).Biographies of Muhammad record incidences showing his kindness and leniency to others. Once, a man came to him and said that he had committed a certain sin. As reparation for his sin, Muhammad asked the man if he could free a slave upon which the man expressed his inability. Muhammad asked him if he could fast for two months upon which the man replied in the negative. Muhammad asked him again if he could feed sixty poor men upon which the man replied that he was even unable to do that. In the meantime, a bag of dates was brought there as gift for Muhammad. Muhammad gave the bag of dates to the man and told him to distribute the dates among the poor as reparation. The man passionately said "who is poorer than me in Madina?" Hearing this, Muhammad smiled and told the man to distribute the dates among his own family members. Charity, Forgiveness and Honesty remove the crisis of morals and values.

The Quran uses the words adl, qist, qast, was at, and Mizan in referring to Justice, with the word adl being mostly used and literally meaning to straighten, to balance, to depart from wrong, or to be equal (Khadduri, 1984) Its meaning is thus "a combination of moral and social values denoting fairness, balance, temperance and straightforwardness." In Islam, justice is not only a moral virtue but also an obligation to be fulfilled under all circumstances. The Quran at its two hundred places warns people against injustice, and at its one hundred places directs people to establishing justice.The Quran served for the early Muslims, as it serves for the present Muslims, as the primary source for the notion of justice. As his capacity as a prophet, the Quranic notion of justice was explained and translated into practice by Muhammad in dealing with various social issues, thus setting moral and legal examples and standards of justice in society and paving ways for the later Muslim theologians and scholars to "formulate theories of justice". As Almighty Allah says about justice "O you who believe, stand firm for justice even against your own selves" (Al-Quran 4: 135) According to the scholars of the Quran, rendering justice to people is a trust from God entrusted on mankind, and this should be fulfilled with a sense of responsibility, not just as a formality (Justice in Islam, 2006). In Islamic sharia, fulfilling a contract is regarded as compulsory (Al-Quran 17:34) and is one of the three qualities necessary for becoming a true Muslim( Sahih Muslim Chapter 2, Hadith 177), as the famous hadith says "Three are the signs of a hypocrite, even if he observed fast and prayed and asserted that he was a Muslim: when he spoke he told a lie, when he made promise he acted treacherously, and when 
he was trusted he betrayed"(Sahih Muslim, Chapter 1, Hadith 113). Both the Quran and the hadith have attached importance to respect a contract once it has been made, and whether the other party is a Muslim or non-Muslim (Al Ghazali chp-9). In Islamic tradition, fulfillment of promises has some other dimensions. Islamic belief holds that before creating humans in this world, God assembled their souls and asked them if He was not their Lord upon which they replied in the affirmative. Thus, accepting Allah as true God and following His commands in all sphere of life is regarded as the greatest fulfillment of that covenant (Al-Quran 7:172). Again, in case of Muslim Marriage, full payment of Mahr the amount of money which a bridegroom needs to pay to the bride at the time of their marriage has been emphasized. Non-payment, partial payment, or manipulation of mahr (jointure) is seen as the disruption of marriage contract. A hadith in Tibrani says "If a man has married a woman and in his heart he has the intention of not paying that mahr, then he has deceived her. If he dies and he has not paid her right, then on the Day of Judgment he will be presented before Allah as a rapist.And a man who has borrowed money from another man while he did not have the intention of re-paying the debt, then he has deceived him, and consequently he defrauded him. If he dies in this condition, without paying back his debt, then he will meet Allah as a thief." Patience has a great value in Islam. Islamic tradition holds that God has made this world to test ground for mankind, especially for the believers, and that the sincerity and strength of their faith will be judged through various trials (Ghazali, chp-8). Patience is one of the moral qualities which Islamic shariah considers necessary for a Muslim in order to keep away from evildoings, and in a broader sense, to protect his faith (Al-Quran 2:177

If the above discussion is followed, the crisis of morals values will be removed from society and Bangladesh will be enriched country all over the world.

\section{Conclusion}

To sum up, this study about the crisis of morals and values reveals that it has come to such an extent that it cannot be discarded as a negligible issue. It is eroding the vitals of our nation day by day. Except a good number of men and women of upright thinking and ethical consideration it affects all other people. Our young boys and girls are not free from the effects of the evils of immorality. Those who are morally weak succumb to the lure of the immoral practices. Success gained by fraudulent men and at the cost of moral principle cannot endure for long because the touch of truth is the touch of life which we expect should be the foundation of the society. Courtesy, honesty, sincerity, kindness, compassion, fellow feeling, respect for superiors and sacrifice for others were the cardinal virtues which in the past were cultivated and practiced by all those who were living in the society as norms and standards. Now a days all these values are few and far between in our modern society where we are awfully busy only with ourselves. As a result human life has become awesome and deplorable. To get rid of this malady we have to change our minds and enlightening the mind the cure must be sought through governmental and individual effort. A nation unblessed by divine light and humanitarian spirit cannot stand upright. In this context the cultivation of the moral and spiritual values among our youths should be brought to the limelight because they are the torch bearers of the nation. This is how we can encounter the challenging task by which human beings are beset with.

\section{References}

A, Anis. (2015). "Vlues, Ethics and morality fleeting 'alarmingly' in Bangladesh”. The Daily Observer. January 25, 2015.

Abass, I. M. (1998). "The emerging Trends in rural-urban migration in Nigeria: A paper presented at Habitat-Afrique 2000" International Conference and Exposition organized by the Department of Architecture, Ahammed Bello University, Zaria, Nigeria.

Abdur Raheem, M. R. M. (1988). Muhammad the Prophet. Pustaka Nasional Pte Ltd. p. 712. ISBN 9789971772239.

Achebe, C. (1958). Things Fall Apart. London: Heinemann.

Aisha Stacey. (2012). Anger management in Islam: Controlling anger is a sign of righteousness. IslamReligion.com Retrieved 19 Aug 2016.

Al-Ghazali,M. (2004). Muslim's Character. English translation by Mufti A. H. Usmani. ISSN 978-1567447262.

Ali, Abbas J. (2015). Handbook of Research on Islamic Business Ethics. Edward Elgar Publishing. ISSN 9781781009451.

Alkhuli, M. A. (2006). The Need For Islam. Al Manhal. ISSN 9789957401627.

Ameer, H. (2013). Moral values in Islam, The independent weekly news paper supplement column, Dhaka. www.independent.weeklynews/islam.bd.com

Barker (2012). The politics of Aristotle. Oxford: Oxford University Press. ISBN 978-0199797783

Bayak al-Jerrahi al-Halveti. (2005). Canada: World Wisdom, Inc. ISSN no- 941532-68-2

Bentley, D. (1999). The 99 Beautiful Names for God for All the People of the Book. William Carey Library. 
ISBN 0-87808-299-9.

Birgivi, I. (2005). The Path of Muhammad: A Book on Islamic Morals and Ethics. Translated by Shaykh Tosun.

Buhl, F.; \& Welch, A. T. (1993). "Muḥammad". Encyclopaedia of Islam 7. pp. 360-376.

Clark, M. (2011). Islam For Dummies. John Wiley \& Sons. ISBN 978-1-118-05396-6.

Ebhomele, E., \& Ateba, S. (2013). "David West: Nigerian Churches Stink with Corruption” www.pmnewsnigeria.com / 2013/5/17/david-west-nigerian-churhe-stink-with-corruption.html. Accessed on 14/8/2013.

Hashmi, S. H. (2009). Islamic Political Ethics: Civil Society, Pluralism, and Conflict. Princeton University Press. ISBN 9781400825370.

Haykal, M. H. (2008). The Life of Muhammad. Selangor: Islamic Book Trust. p. 486. ISBN 978-983-9154-17-7.

Iheanacho, N. (2010). "A Critical look at Contemporary Nigerian Christianity" in Journal of Performed Theology. Nsukka: Society for Academic Excellence.

Imam, K. M. (2006). Modesty: An Overview. IslamReligion.com Retrieved 19 Aug 2016.

Justice in Islam. (2006). Retrieved from IslamReligion.com 19 Aug 2016.

Khadduri, M. (1984). The Islamic Conception of Justice. The Johns Hopkins University Press. ISBN 9780801869747

Khan, M. Z. (1980). Muhammad: Seal of the Prophets. Routledge \& Kegan Paul. ISBN 0-7100-0610-1.

Leaman, O. (2006). The Qur'an: An Encyclopedia. Taylor \& Francis. ISSN No- 9780415326391.

Leaman. (2006). System of Islam, The Standard of Morality. IslamReligion.com Retrieved 19 Aug 2016

Maariful Quran (exegesis of the Quran (2007) by Muhammad Shafi Usmani, Karachi. ISSN 260-8-61530-4576.

Mohammad, H. K. (2012). Islam and the Fate of Others: The Salvation Question. Oxford University Press. pp 65-94. ISBN 978-0199796663

Priyanka, T., \& Sakshi, M. (2013). Erosion of Moral Ethics among Military Personnel. IOSR Journal of Humanities and Science, 11(6), 24-29.

Sahih Al Bukhari translated by Abdur Rahim (2003), Islamic foundation Bangladesh, Dhaka. Islamic foundation press, Dhaka.

Schweneke, C. G. (2002). "The moral Challenge of urbanization in less developed counties" www.deve.opment values met/.../ urbanization \% 20.

Shibli, N. (2006). Volume-1, Sirat-un-Nabi. Islamic foundation Pakistan, Lahore.ISBN-087-276084760.

Stefon, M. ed. (2010). Islamic Beliefs and Practices. New York: Britannica Educational Publishing. ISBN 978-1-61530-060-0.

Turner, B. S. (2008). The Body and Society: Explorations in Social Theory. p. 5. SAGE. ISSN No. 9781412929875

\section{Copyrights}

Copyright for this article is retained by the author(s), with first publication rights granted to the journal.

This is an open-access article distributed under the terms and conditions of the Creative Commons Attribution license which permits unrestricted use, distribution, and reproduction in any medium, provided the original work is properly cited. 